\title{
Pengaruh Idealisme, Kecerdasan Emosional dan Etika pada Persepsi Etis Mahasiswa Profesi Akuntansi dengan Kepercayaan Diri
}

\author{
Ayu Listya Adriani Sidartha ${ }^{1}$ \\ Fakultas Ekonomi dan Bisnis \\ Universitas Udayana, Indonesia
}

\author{
I Ketut Sujana ${ }^{2}$ \\ Fakultas Ekonomi dan Bisnis \\ Universitas Udayana, Indonesia
}

\begin{abstract}
Surel : adrianitya79@gmail.com
ABSTRAK

Penelitian ini bertujuan untuk mengetahui pengaruh idealisme, kecerdasan emosional dan etika pada persepsi etis mahasiswa profesi akuntansi mengenai perilaku etis akuntan dengan kepercayaan diri sebagai pemoderasi. Populasi dalam penelitian ini Mahasiswa Pendidikan Profesi Akuntansi (PPAk) dan jumlah sampel sebanyak 40 mahasiswa profesi akuntansi dengan menggunakan teknik penentuan data sampel jenuh. Teknik analisis data yang digunakan yaitu Moderated Regression Analysis. Hasil penelitian ini menunjukkan bahwa idealisme, kecerdasan emosional dan etika berpengaruh positif signifikan terhadap persepsi etis mahasiswa profesi akuntansi mengenai perilaku etis akuntan dan hasil penelitian dari kepercayaan diri sebagai variabel pemoderasi, menunjukkan bahwa kepercayaan diri mampu memperkuat pengaruh idealisme, kecerdasan emosional dan etika pada persepsi etis mahasiswa profesi akuntansi mengenai perilaku etis akuntan.
\end{abstract}

Kata Kunci: Idealisme; Kecerdasan Emosional; Etika; Persepsi Etis; Kepercayaan Diri.

\section{Effects of Idealism, Emotional Intelligence and Ethics on Ethical Perceptions Accounting Profession Students with Confidence}

\section{ABSTRACT}

This study aims to determine the influence of idealism, emotional intelligence and ethics on the ethical perceptions of accounting profession students regarding the ethical behavior of accountants with self-confidence as a moderating factor. The population in this study Accounting Professional Education Students (PPAk) and the total sample of 40 accounting profession students using the technique of determining the sample of saturated data. The data analysis technique used is Moderated Regression Analysis. The results of this study indicate that idealism, emotional intelligence and ethics have a significant positive effect on the ethical perceptions of accounting profession students regarding the ethical behavior of accountants and the results of research on self-confidence as a moderating variable, showing that self-confidence is able to strengthen the influence of idealism, emotional intelligence and ethics on ethical perception accounting profession students regarding the ethical behavior of accountants.

Keywords: Idealism; Emotional Intelligence; Ethics; Ethical Perception; Confidence.

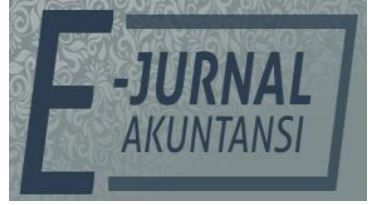

e-ISSN 2302-8556

Vol. 30 No. 8

Denpasar, Agustus 2020

Hal. 2138-2151

10.24843/EJA.2020.v30.i08.p19

PENGUTIPAN:

Sidartha, A. L. A. \& Sujana, I K. (2020). Pengaruh Idealisme, Kecerdasan Emosional dan Etika pada Persepsi Etis Mahasiswa Profesi Akuntansi dengan Kepercayaan Diri. EJurnal Akuntansi, 30(8), 2138 -

2151

RIWAYAT ARTIKEL: Artikel Masuk: 5 Maret 2020 Artikel Diterima: 9 Agustus 2020

Artikel dapat diakses : https://ojs.unud.ac.id/index.php/Akuntansi/index 


\section{PENDAHULUAN}

Akuntan merupakan profesi yang sangat penting dalam bidang ekonomi dan bisnis, terutama dalam penyediaan informasi akuntansi bagi pihak-pihak yang berkepentingan. Menurut Lubis (2014) pentingnya profesi akuntansi dan aktivitas yang dilakukannya dalam sebuah bisnis modern tidak diragukan lagi. Hal ini dikarenakan pemilik, manajer dan investor mengambil keputusan ekonomi berdasarkan informasi akuntansi yang disediakan akuntan. Ketepatan dari pengambilan keputusan tersebut tergantung dari kualitas informasi yang diberikan akuntan. Selain sebagai pertimbangan dalam pengambilan keputusan, informasi akuntansi merupakan sumber yang digunakan untuk mengevaluasi dan menilai kinerja perusahaan (Yani, 2011).

Banyaknya kasus yang terkait dengan tindakan-tindakan tidak etis menjadikan isu etika selalu menarik untuk dikaji. Bidang profesi akuntansi tidak luput dari pelanggaran dan kecurangan yang menimbulkan krisis etika, ini disebabkan karena kurangnya perhatian terhadap nilai-nilai profesional, obyektivitas dan kepentingan publik sehingga perilaku etis akuntan menjadi krisis kepercayaan (Mabil, 2019). Krisis kepercayaan ini diketahui dengan maraknya kasus pelanggaran etika yang melibatkan para akuntan (Ariyanti \& Widanaputra, 2018).

Salah satu permasalahan profesi akuntan adalah kasus Garuda Indonesia. Pusat Pembinaan Profesi Keuangan Kementerian Keuangan (PPPK Kemenkeu) menemukan pelanggaran yang dilakukan oleh Akuntan Publik (AP) atau auditor Kantor Akuntan Publik (KAP) yang melakukan audit terhadap PT Garuda Indonesia Tbk dimana hal itu memengaruhi opini laporan auditor independen. Selain itu, KAP dianggap belum menerapkan sistem pengendalian mutu secara optimal terkait konsultasi dengan pihak eksternal. Oleh karena itu, Kementerian Keuangan menjatuhkan sanksi pembekuan izin selama 12 bulan kepada AP Kasner Sirumapea dan KAP Tanubrata, Sutanto, Fahmi, Bambang \& Rekan, selaku auditor laporan keuangan PT. Garuda Indonesia (Persero) Tbk dan Entitas Anak Tahun Buku 2018. PPPK, sebagai lembaga yang berada di Bawah Kemenkeu, menilai Kanser belum sepenuhnya mematuhi Standar Audit (SA) 315 terkait Pengidentifikasian dan Penilaian Risiko Kesalahan Penyajian Material melalui Pemahaman atas Entitas dan Lingkungannya. Kanser juga dinilai tak bisa mempertimbangkan fakta-fakta setelah tanggal laporan keuangan sebagai dasar perlakuan, sehingga auditnya tak sesuai dengan SA 500 dan SA 560. Kesalahan audit itu muncul terkait piutang Rp 2,9 triliun atas kerja sama pemasangan Wi-Fi dengan PT Mahata Aero Teknologi yang dicatat sebagai pendapatan dalam laporan keuangan Garuda tahun lalu. Sesuai Peraturan Standar Akuntansi Keuangan (PSAK) 23, piutang tidak dapat dianggap sebagai pendapatan (Fabian, 2019).

Masih banyak terdapat kasus pelanggaran kode etik profesi akuntansi. Seharusnya kasus pelanggaran etika tidak terjadi apabila setiap akuntan mempunyai pengetahuan, pemahaman dan kemampuan untuk menerapkan nilai-nilai moral dan etika secara memadai dalam pelaksanaan pekerjaannya. Dari berbagai kasus yang telah terjadi, dapat disimpulkan betapa pentingnya pendidikan etika kepada mahasiswa karena pendidikan etika dan profesionalisme dalam bidang akuntansi dipandang sebagai salah satu cara 
untuk mengatasi krisis etika profesi (Jackling et al., 2007). Adanya perilaku tidak etis yang dilakukan akuntan sangatlah menarik untuk mengetahui reaksi dan persepsi mahasiswa akuntansi tentang penting atau tidaknya memiliki perilaku etis yang melibatkan profesi akuntan.

Perilaku mahasiswa perlu diteliti untuk mengetahui sejauh mana mereka akan berperilaku etis atau tidak di masa yang akan datang. Masalah etika menjadi suatu isu yang penting dalam bidang akuntansi di perguruan tinggi, karena lingkungan pendidikan memiliki andil dalam membentuk perilaku mahasiswa untuk menjadi seorang yang profesional (Elias \& Farag, 2010). Persoalan kasus yang melibatkan profesi akuntan seharusnya ada di dalam proses pendidikan akuntansi yang ada di perguruan tinggi agar mahasiswa mengetahui pentingnya nilai-nilai etis dalam bisnis untuk memperkuat pentingnya etika, adanya etis studi kasus dan analisis kritis perlu dimasukkan ke dalam diskusi di semua bisnis dan topik kursus manajemen dan bukan hanya memperlakukan etika sebagai modul (Shawver et al., 2015). Hal ini menunjukkan bahwa sikap dan perilaku etis akuntan dapat terbentuk melalui proses pendidikan yang terjadi dalam institusi pendidikan yang memiliki program studi akuntansi (Lucyanda \& Endro, 2013). Penelitian ini dilakukan di mahasiswa Program Pendidikan Profesi Akuntansi (PPAk) Universitas Udayana karena PPAk menyiapkan akuntan profesional yang unggul, mandiri dan berbudaya di kawasan Asia Tenggara tahun 2020.

Teori moral kognitif dapat dikaitkan dengan perilaku etis. Teori moral kognitif membahas tentang proses pengambilan keputusan manusia yang berpandangan bahwa perkembangan moral merupakan dasar dari perilaku etis. Kohlberg (1971) mengkategorikan respon yang dimunculkan ke dalam enam tahap yang berbeda. Keenam tahap tersebut dibagi kedaalam tiga tingkatan: preconventional, conventional, post-conventional. Akuntan sebagai suatu profesi pada tahapan tertinggi dalam teori moral kognitif yaitu post-conventional akan menunjukkan kematangan moral yang tinggi, hal ini dikarenakan tingkat pemahaman mengenai aturan dan hukum yang berlaku sudah mendalam. Kematangan moral menjadi dasar dan pertimbangan akuntan dalam merancang tanggapan dan sikap terhadap isu-isu etis serta dilema etis yang dihadapi (Fan et al., 2013). Pemahaman aturan dan moralitas yang tinggi diharapkan menurunkan perilaku tidak etis dan kecurangan akuntansi yang dilakukan.

Faktor-faktor yang memengaruhi terjadinya perilaku etis dalam penelitian ini menggunakan variabel idealisme, kecerdasan emosional, etika dan kepercayaan diri sebagai variabel pemoderasi. Idealisme merupakan suatu sikap yang menganggap bahwa tindakan yang tepat atau benar akan menimbulkan konsekuensi sesuai hasil yang diinginkan. Seseorang individu yang memiliki sifat idealis akan menghindari berbagai tindakan yang dapat menyakiti atau merugikan orang lain, seorang idealis akan mengambil tindakan tegas terhadap suatu tindakan tegas terhadap suatu kejadian yang tidak etis. Penelitian yang dilakukan oleh Cahyani \& Ramantha (2018) menunjukkan bahwa tingkat idealisme berpengaruh pada opini mahasiswa terhadap perilaku etis akuntan. Hasil penelitian tersebut juga didukung oleh Damayanthi \& Juliarsa (2016) memberi petunjuk bahwasannya idealisme memiliki pengaruh positif pada 
perilaku etis. Ini berarti bahwa hubungan idealisme searah dengan perilaku etis akuntan.

Lingkungan kerja menuntut seseorang untuk bertindak profesional dan bersikap etis. Tidak hanya kepintaran yang diperlukan dalam bersaing di dunia kerja, namun kecerdasan emosional juga penting dimiliki (Kurniasari \& Budiasih, 2018). Kemampuan seseorang ditentukan oleh kecerdasan yang dimiliki antara lain adalah kecerdasan intelektual, kecerdasan emosional dan kecerdasan spiritual (Martini \& Mimba, 2017). Seseorang yang memiliki kecerdasan emosional akan mampu mengatur suasana hatinya dengan baik agar tidak melumpuhkan kejernihan berpikir secara rasional. Kecerdasan emosional berperan penting dalam pekerjaan seseorang (Putra \& Latrini, 2016). Kecerdasan emosional menuntut pemilikan perasaan, untuk belajar mengakui, menghargai perasaan pada diri dan orang lain serta menanggapinya dengan tepat, menerapkan secara efektif energi emosi dalam kehidupan sehari-hari (Part, 2010). Hasil penelitian yang dilakukan oleh Kurniasari \& Budiasih (2018), menunjukkan bahwa kecerdasan emosional berpengaruh terhadap perilaku etis. Kemampuan seseorang ditentukan oleh kecerdasan yang dimiliki antara lain adalah kecerdasan intelektual, kecerdasan emosional dan kecerdasan spiritual (Martini \& Mimba, 2017). Kecerdasan intelektual, kecerdasan emosional dan kecerdasan spiritual merupakan hal yang sangat penting dan harus dikembangkan dalam kehidupan seseorang menurut Sujana \& Laksmi (2017), sehingga ketiga kercerdasan tersebut adalah kemampuan individu yang akan berdampak pada kinerja yang baik (Sujana et al., 2019). Dengan begitu seseorang yang memiliki kecerdasan emosional dapat berperilaku dengan etis.

Faktor lain yang memengaruhi seseorang berperilaku etis adalah etika. Seseorang yang memiliki etika dapat berperilaku dengan etis karena seseorang yang mempunyai etika akan mengetahui tindakan yang benar dan yang salah sesuai dengan nilai yang berlaku di masyarakat. Penelitian yang dilakukan oleh Yanti (2016) menunjukkan bahwa etika berpengaruh signifikan positif terhadap perilaku etis akuntan. Mahasiswa yang memiliki etika tinggi akan lebih bersikap bijaksana dan memberikan tanggapan baik terhadap perilaku etis.

Riset sebelumnya yang berkaitan dengan perilaku etis sudah banyak dilakukan di Indonesia membuat peneliti ingin melakukan penelitian dengan menambahkan variabel pemoderasi. Variabel pemoderasi digunakan pada penelitian ini adalah kepercayaan diri. Variabel pemoderasi nantinya dapat membuktikan apakah variabel moderasi mampu memengaruhi secara langsung pengaruh variabel independen pada variabel dependen (Lie, 2009).

Salah satu faktor yang memengaruhi perilaku etis adalah kepercayaan diri. Kepercayaan diri mampu memengaruhi aspek individual seseorang untuk berperilaku etis. Hal ini sesuai dengan penelitian Rini (2002) yang menyatakan bahwa kepercayaan diri adalah sikap positif seorang individu yang memampukan dirinya untuk mengembangkan penilaian positif baik terhadap diri sendiri maupun terhadap lingkungan atau situasi yang dihadapi. Berdasarkan penelitian Aziza \& Melandy (2006) kepercayaan diri sebagai variabel moderating karena secara teoritis kemampuan seseorang untuk percaya akan kemampuan yang dimiliki dirinya akan memengaruhi kecerdasan orang tersebut sehingga dapat berperilaku etis. Kepercayaan diri merupakan kesadaran 
yang kuat tentang harga dan kemampuan diri sendiri atau kemampuan yang dapat memperkuat atau memperlemahkan seseorang dalam meningkatkan pemahaman akuntansi dan mencapai tujuan dan cita-citanya, sehingga tingkat kepercayaan diri memengaruhi sikap individu seseorang untuk kemudian dapat bersikap kurang atau lebih beretika (Goleman, 2018).

Dalam bertindak seseorang harus memperhatikan peraturan dan etika yang berlaku. Individu yang memiliki sifat idealis akan berpegang teguh pada aturan moral yang bersifat universal. Individu yang idealis mempunyai prinsip bahwa merugikan individu lain adalah hal yang selalu dihindari dan mereka tidak akan melakukan tindakan yang mengarah pada tindakan yang berkonsekuensi negaif (Nurmala, 2010).

Pada penelitian yang dilakukan oleh Milyawati (2017) menemukan adanya pengaruh positif pada persepsi etis mahasiswa. Penelitian yang dibuat oleh Damayanthi \& Juliarsa (2016) dan Kurniasari \& Budiasih (2018) menunjukkan bahwa mahasiswa yang bersifat idealis cenderung memberikan tanggapan atau presepsi ketidaksetujuaan terhadap perilaku tidak etis akuntan.

$\mathrm{H}_{1}$ : Idealisme berpengaruh positif pada persepsi etis mahasiswa profesi akuntansi mengenai perilaku etis akuntan.

Menurut teori moral kognitif, seseorang yang telah di tahapan postconventional (tahapan tertinggi) akan menunjukkan kematangan moral yang tinggi hal ini dikarenakan tingkat pemahaman mengenai aturan dan hukum yang berlaku sudah mendalam. Seseorang yang memiliki pemahaman yang mendalam lebih dapat mengontrol emosinya sehingga dapat berpikir rasional dalam berperilaku. Kecerdasan emosional adalah kemampuan seseorang untuk menerima, menilai, mengelola, serta mengontrol emosi dirinya dan orang lain disekitarnya. Kecerdasan emosional berperan penting dalam pekerjaan seseorang (Putra \& Latrini, 2016). Kemampuan mahasiswa dalam mengendalikan emosi sesuai dengan keinginan dan kemampuan untuk mengendalikan emosi akan berdampak positif. Dapat di simpulkan kecerdasan emosional adalah kemampuan seseorang untuk memahami serta mengatur suasana hati agar tidak melumpuhkan kejernihan berpikir secara rasional. Hasil penelitian yang di lakukan oleh Lucyanda \& Endro (2013) menunjukkan bahwa kecerdasan emosional berpengaruh terhadap perilaku etis. Penelitian lain yang menunjukkan hasil yang sama adalah penelitian yang dilakukan Suwarno \& Cahyano (2013).

$\mathrm{H}_{2}$ : Kecerdasan emosional berpengaruh positif pada persepsi etis mahasiswa profesi akuntansi mengenai perilaku etis akuntan.

Menurut Kohlberg (1971) menyatakan teori moral kognitif tentang proses pengambilan keputusan manusia yang berpandangan bahwa perkembangan moral merupakan dasar dari perilaku etis. Kematangan moral menjadi dasar dan pertimbangan seseorang dalam merancang tanggapan dan sikap terhadap isu-isu etis yang dihadapi. Pemahaman aturan dan moralitas yang tinggi diharapkan menurunkan perilaku tidak etis. Dengan mempelajari etika dapat membantu seseorang untuk membedakan mana yang benar dan mana yang salah, sehingga seseorang akan lebih peka terhadap persoalan yang ada. Seseorang yang memiliki etika akan lebih bijaksana dan peka terhadap persoalan yang ada sehingga akan lebih kritis dalam menerima informasi dan dapat mempengaruhi 
persepsi seseorang. Menurut Yanti (2016) dengan dimasukkannya isu-isu dan pembelajaran etika dalam pelajaran akuntansi, dapat melatih mahasiswa untuk membentuk persepsinya dalam memandang kejadian atau informasi yang diterima. Dalam memberikan tanggapan mengenai prinsip etika profesi akuntan, mahasiswa yang memiliki etika tinggi akan lebih bersikap bijaksana dan memberikan tanggapan baik terhadap perilaku etis dibandingkan dengan mahasiswa yang memiliki etika rendah yang akan memberikan tanggapan bahwa bersikap melanggar etika adalah suatu sikap yang tidak merugikan (Hanny, 2016). Dari penjelasan, maka hipotesis yang dapat dirumuskan adalah:

$\mathrm{H}_{3}$ : Etika berpengaruh positif pada persepsi etis mahasiswa profesi akuntansi mengenai perilaku etis akuntan.

Menurut teori moral kognitif Kohlberg (1969), perkembangan moral mulai tumbuh dengan bertambahnya usia, karena semakin bertambahnya usia maka semakin banyak seseorang mendapatkan pengalaman. Semakin banyak pengalaman yang didapat seseorang, maka semakin dapat berperilaku etis. Idealisme adalah sikap perilaku seseorang agar tidak membuat pelanggaran pada nilai-nilai etika yang dapat membuat orang lain rugi. Seseorang yang memiliki idealis yang tinggi memiliki prinsip bahwa membuat individu lain merugi merupakan hal yang selalu bisa dihindari. Menurut Rini (2002) yang menyatakan bahwa kepercayaan diri adalah sikap positif seorang individu yang memampukan dirinya untuk mengembangkan penilaian positif baik terhadap diri sendiri maupun terhadap lingkungan atau situasi yang dihadapinya. Kepercayaan diri seorang mahasiswa akuntansi juga dianggap akan lebih membentuk sikap etis dalam menyatakan kebenaran akan diri sendiri dan memberikan penilaian objektivitas tanpa harus merasa tertekan. Maka seseorang yang memiliki kepercayaan diri kuat akan selalu mempercayai dirinya bahwa ia bisa melakukan sesuatu dengan baik tanpa harus merugikan orang lain. Dari penjelasan, maka hipotesis yang dapat dirumuskan adalah:

$\mathrm{H}_{4}$ : Kepercayaan diri memperkuat pengaruh idealisme pada persepsi etis mahasiswa profesi akuntansi mengenai perilaku etis akuntan.

Perkembangan moral sangat dipengaruhi oleh perkembangan mental (Kohlberg, 1971). Semakin tinggi tahapan perkembangan moral seseorang maka semakin banyak pengalaman yang dimiliki dan semakin baik pula kemampuan seseorang untuk mengontrol emosinya dalam mengambil suatu keputusan sesuai dengan prinsip-prinsip etika yang ada. Kecerdasan emosional yang baik dapat dilihat dari kemampuan mengenal diri sendiri, mengendalikan diri, memotivasi diri, berempati, dan kemampuan sosial. Oleh karena itu, mahasiswa yang memiliki keterampilan emosi yang baik akan berhasil di dalam kehidupannya. Angelis (2005) menyatakan ada beberapa cara untuk mengembangkan kekuatan dan kelemahan dalam pengenalan diri yaitu intropeksi diri, mengendalikan diri, membangun kepercayan diri, mengenal dan mengambil inspirasi dari tokoh-tokoh teladan, dan berfikir positif dan optimis tentang diri sendiri.

Seseorang yang memiliki kecerdasan emosional yang baik akan mudah bergaul dengan baik, mengenali dirinya, dan memiliki tanggungjawab dalam kehidupannya. Sehingga, akan membuat seseorang memiliki rasa percaya diri. Pelatihan kecerdasan emosional merupakan salah satu faktor yang 
mempengaruhi kepercayaan diri dimana seseorang akan mampu atau berani menunjukkan potensi yang dimilikinya, sehingga mereka mampu mencapai tujuan hidup dengan sukses. Hasil penelitian Dewi \& Wirama (2016) menunjukkan bahwa terdapat pengaruh signifikan antara kecerdasan emosional dengan kepercayaan diri. Dari penjelasan, maka hipotesis yang dapat dirumuskan adalah:

$\mathrm{H}_{5}$ : Kepercayaan diri memperkuat pengaruh kecerdasan emosional pada persepsi etis mahasiswa profesi akuntansi mengenai perilaku etis akuntan.

Seiring peningkatan tahapan perkembangan moral dalam teori moral kognitif, makin baik pula kemampuan dalam menyadari berbagai tindakan yang ada disekitarnya dan semakin banyak pengalaman yang dimiliki sehingga pada tahap perkembangan moral yang paling tinggi individu akan bersikap sesuai dengan prinsip etika yang berlaku. Etika adalah sebuah prinsip moral serta perbuatan yang dijadikan dasar tindakan seseorang hingga apa yang dilaksanakannya diberi pandangan oleh masyarakat sebagai kegiatan terpuji. Sebagai seorang akuntan yang profesional harus menyadari adanya tanggung jawab kepada publik, klien, dan kepada sesama rekan praktisi, termasuk perilaku yang terhormat, bahkan jika hal tersebut berarti mengorbankan kepentingan pribadi.

Fereira seorang konsultan dari Deloitte and Touche Consulting mengatakan bahwa seorang yang memiliki kepercayaan diri, disamping mampu mengendalikan dan menjaga keyakinan dirinya, juga akan mampu membuat perubahan lingkungan (Agustian, 2004). Seseorang yang memiliki kepercayaan diri yang kuat akan lebih mengenal dirinya lebih baik dan percaya bahwa ia bisa mengerjakan sesuatu dengan kemampuannya tanpa melakukan sesuatu yang melanggar etika. Dengan demikian seseorang yang memiliki kepercayaan diri yang kuat berpengaruh positif terhadap potensi dalam dirinya yang mampu meningkatkan nilai etika. Dari penjelasan, maka hipotesis yang dapat dirumuskan adalah:

$\mathrm{H}_{6}$ : Kepercayaan diri memperkuat pengaruh etika pada persepsi etis mahasiswa profesi akuntansi mengenai perilaku etis akuntan.

\section{METODE PENELITIAN}

Penelitian ini dilakukan pada mahasiswa Program Pendidikan Profesi Akuntansi (PPAk) di Fakultas Ekonomi dan Bisnis Universitas Udayana yang terletak di Jalan P.B. Sudirman, Denpasar, Bali, Indonesia. Obyek pada penelitian ini adalah persepsi mahasiswa PPAk di Fakultas Ekonomi dan Bisnis Universitas Udayana. Mahasiswa PPAk dipilih karena telah menempuh semua mata kuliah dan sudah menjurus ke profesi akuntansi yang dimana PPAk menyiapkan akuntan profesional yang unggul, mandiri dan berbudaya di kawasan Asia Tenggara tahun 2020.

Populasi dalam penelitian ini adalah mahasiswa Program Pendidikan Profesi Akuntansi (PPAk) angkatan 2019 Fakultas Ekonomi dan Bisnis, Universitas Udayana. Teknik penentuan sampel pada penelitian ini adalah dengan menggunakan menggunakan simple random sampling. Jadi, jumlah sampel yang akan diteliti adalah sebanyak 40 orang. 
Teknik analisis regresi moderasi digunakan untuk menguji variabel moderasi, dimana MRA merupakan aplikasi khusus regresi yang dalam persamaan regresinya mengandung unsur interaksi perkalian dua atau lebih variabel independen (Lie, 2009). Variabel moderating yaitu kepercayaan diri mempengaruhi hubungan langsung antara variabel independen idealisme, kecerdasan emosional dan etika dengan variabel dependen yaitu persepsi mahasiswa akuntansi mengenai perilaku etis akuntan. Adapun persamaan regresi yang dihasilkan dari model regresi dalam penelitian ini, yaitu:

$Y=\alpha+\beta_{1} X_{1}+\beta_{2} X_{2}+\beta_{3} X_{3}+\beta_{4} X_{1} Z+\beta_{5} X_{2} Z+\beta_{6} X_{3} Z+\varepsilon$

Keterangan

$\mathrm{Y} \quad=$ Pemahaman Akuntansi

a $\quad=$ Konstanta

$\beta_{1}-\beta_{6}=$ Koefisien Regresi

$\mathrm{X}_{1} \quad=$ Idealisme

$\mathrm{X}_{2} \quad=$ Kecerdasan Emosional

$\mathrm{X}_{3}=$ Etika

$\mathrm{Z} \quad=$ Kepercayaan Diri

$\mathrm{X}_{1} \mathrm{Z}=$ Interaksi antara Idealisme dengan Kepercayaan Diri

$\mathrm{X}_{2} \mathrm{Z}=$ Interaksi antara Kecerdasan Emosional dengan Kepercayaan Diri

$\mathrm{X}_{3} \mathrm{Z}=$ Interaksi antara Etika dengan Kepercayaan Diri

$\varepsilon \quad=$ Standar error

\section{HASIL DAN PEMBAHASAN}

Analisis statistik deskriptif yaitu analisis yang menguraikan tentang faktor-faktor yang berpengaruh pada persepsi etis mahasiswa yang terjadi dilapangan untuk memperoleh gambaran yang jelas dan objektif tentang hasil penelitian. Setiap jawaban kuesioner mempunyai bobot atau skor nilai dengan Skala Likert sebagai berikut: skor 4 untuk jawaban sangat setuju dengan kode SS, skor 3 untuk jawaban setuju dengan kode $S$, skor 2 untuk jawaban tidak setuju dengan kode TS, skor 1 untuk jawaban sangat tidak setuju dengan kode STS. Hasil statistik deskriptif dapat dilihat pada Tabel 1.

Tabel 1. Hasil Statistik Deskriptif Variabel Penelitian

\begin{tabular}{lccccc}
\hline \multicolumn{1}{c}{} & $\mathrm{N}$ & Minimum & Maximum & Mean & Std. Deviation \\
\hline Persepsi Etis Mahasiswa & 40 & 5.00 & 10.00 & 7.6000 & 1.49872 \\
Profesi Akuntansi (Y) & & & & & \\
Idealisme (X1) & 40 & 31.00 & 40.00 & 35.2750 & 2.09991 \\
Kecerdasan Emosional (X2) & 40 & 45.00 & 59.00 & 53.1500 & 3.31701 \\
Etika (X3) & 40 & 24.00 & 32.00 & 27.7250 & 2.14820 \\
Kepercayaan Diri (Z) & 40 & 30.00 & 40.00 & 35.4500 & 2.30885 \\
Valid N (listwise) & 40 & & & & \\
\hline
\end{tabular}

Sumber: Data Penelitian, 2019

Variabel persepsi etis mahasiswa profesi akuntansi mengenai profesi akuntan $(\mathrm{Y})$ menggunakan indikator bertindak berdasarkan kepentingan pribadi dan tidak menerapkan Prinsip Etika Kode Etik IAI yang berjumlah 5 item. Variabel persepsi etis mahasiswa profesi akuntansi memiliki nilai minimum sebesar 5.00 dan nilai maksimum sebesar 10.00 dengan nilai rata-rata sejumlah 7.600. Nilai standar deviasi pada variabel persepsi etis mahasiswa profesi 
akuntansi mengenai perilaku etis akuntan $(Y)$ sebesar 1.49872. Statistik deskriptif dalam penelitian ini menunjukkan rata-rata skor jawaban variabel Y lebih besar dari standar deviasi yang artinya sebaran data berdistribusi normal, sehingga dapat disimpulkan dari 40 responden sebagian besar menyetujui pertanyaanpertanyaan yang diajukan dalam kuesioner yang berarti mahasiswa profesi akuntansi memiliki persepsi etis mengenai perilaku etis akuntan.

Variabel Idealisme $\left(\mathrm{X}_{1}\right)$ menggunakan indikator perilaku tidak merugikan orang lain yang berjumlah 10 item. Variabel idealisme memiliki nilai minimum sebesar 31.00 dan nilai maksimum sebesar 40.00 dengan nilai rata-rata sejumlah 35.2750. Nilai standar deviasi pada variabel idealisme $\left(X_{1}\right)$ sebesar 2.09991. Statistik deskriptif dalam penelitian ini menunjukkan rata-rata skor jawaban variabel $\mathrm{X}_{1}$ lebih besar dari standar deviasi yang artinya sebaran data berdistribusi normal, dapat disimpulkan dari 40 responden sebagian besar menyetujui pertanyaan-pertanyaan yang diajukan dalam kuesioner yang berarti mahasiswa profesi akuntansi memilki tingkat idealisme yang baik sehingga dapat berperilaku etis.

Variabel Kecerdasan Emosional $\left(\mathrm{X}_{2}\right)$ menggunakan indikator pengendalian diri, kesadaran diri, motivasi diri, empati diri dan keterampilan diri yang berjumlah 15 item. Variabel kecerdasan emosional memiliki nilai minimum sebesar 45.00 dan nilai maksimum 59.00 dengan nilai rata-rata sejumlah 53.1500. Nilai standar deviasi pada variabel kecerdasan emosional $\left(X_{2}\right)$ sebesar 3.31701. Statistik deskriptif dalam penelitian ini menunjukkan rata-rata skor jawaban variabel $\mathrm{X}_{2}$ lebih besar dari standar deviasi yang artinya sebaran data akan berdistribusi normal, dapat disimpulkan dari 40 responden sebagian besar menyetujui pertanyaan-pertanyaan yang diajukan dalam kuesioner yang berarti mahasiswa profesi akuntansi memiliki kecerdasan emosional yang baik sehingga mampu berperilaku etis.

Variabel Etika $\left(X_{3}\right)$ menggunakan indikator perilaku yang berdasarkan kode etik yang berjumlah 8 item. Variabel etika memiliki nilai minimum sebesar 24.00 dan nilai maksimum sebesar 32.00 dengan nilai rata-rata sejumlah 27.7250 . Nilai standar deviasi pada variabel etika $\left(X_{3}\right)$ yaitu sejumlah 2.14820. Statistik deskriptif dalam penelitian ini menunjukkan rata-rata skor jawaban variabel $X_{3}$ lebih besar dari standar deviasi yang artinya sebaran data berdistribusi normal, dapat disimpulkan dari 40 responden sebagian besar menyetujui pertanyaanpertanyaan yang diajukan dalam kuesioner yang berarti mahasiswa profesi akuntansi memiliki etika yang baik sehingga mampu berperilaku etis.

Variabel kepercayaan diri (Z) menggunakan indikator perilaku yang bangga terhadap dirinya sendiri yang berjumlah 10 item. Variabel kepercayaan diri memiliki nilai minimum sebesar 30.00 dan nilai maksimum sebesar 40.00 dengan nilai rata-rata sejumlah 35.4500. Nilai standar deviasi pada variabel kepercayaan diri $(Z)$ sebesar 2.30885. Statistik deskriptif dalam penelitian ini menunjukkan rata-rata skor jawaban variabel $\mathrm{Z}$ lebih besar dari standar deviasi yang artinya sebaran data berdistribusi normal, dapat disimpulkan dari 40 responden sebagian besar menyetujui pertanyaan-pertanyaan yang diajukan dalam kuesioner yang berarti mahasiswa profesi akuntansi memiliki kepercayaan yang baik sehingga mampu berperilaku etis. Hasil uji analisis regresi berganda dapat dilihat pada Tabel 2. 
Tabel 2. Hasil Uji Analisis Regresi Linier Berganda

\begin{tabular}{|c|c|c|c|c|c|}
\hline \multirow[t]{3}{*}{ Model } & \multicolumn{2}{|c|}{$\begin{array}{l}\text { Unstandardized } \\
\text { Coefficients }\end{array}$} & \multirow{3}{*}{$\begin{array}{c}\begin{array}{c}\text { Standardized } \\
\text { Coefficients }\end{array} \\
\text { Beta }\end{array}$} & \multirow[b]{3}{*}{$\mathrm{T}$} & \multirow[b]{3}{*}{ Sig. } \\
\hline & & Std. & & & \\
\hline & B & Error & & & \\
\hline (Constant) & -6.692 & 2.019 & & -3.314 & 0,002 \\
\hline Idealisme (X1) & 0,246 & 0,079 & 0,336 & 3.103 & 0,004 \\
\hline Kecerdasan & 0,197 & 0,046 & 0,431 & 4.257 & 0,000 \\
\hline \multicolumn{6}{|l|}{ Emosional (X2) } \\
\hline Etika (X3) & 0,271 & 0,075 & 0,385 & 3.592 & 0,001 \\
\hline R Square & & & & & 0,646 \\
\hline Adjusted R & & & & & 0,617 \\
\hline \multicolumn{6}{|l|}{ Square } \\
\hline F Hitung & & & & & 21,901 \\
\hline Signifikansi F & & & & & 0,000 \\
\hline
\end{tabular}

Sumber: Data Penelitian, 2019

Berdasarkan Tabel 2, maka disusun persamaan regresi sebagai berikut.

$$
Y=-6.692+0,246 X_{1}+0,197 X_{2}+0,271 X_{3}
$$

Hasil analisis regresi berganda menunjukkan signifikansi seluruh variabel memiliki nilai kurang dari 0,05 yang berarti bahwa terdapat pengaruh yang signifikan pada seluruh variabel bebas terhadap variabel terikat.

Teknik perhitungan dan analisis data menggunakan Moderated Regression Analysis dinyatakan dalam bentuk regresi berganda dengan persamaan yang menggambarkan pengaruh idealisme, kecerdasan emosional dan etika pada persepsi etis mahasiswa profesi akuntansi mengenai perilaku etis akuntan dengan kepercayaan diri sebagai variabel pemoderasi. Perhitungan koefisien regresi dilakukan dengan analisis regresi melalui software SPSS 18.0 for Windows. Hasil pengujian disajikan pada Tabel 3.

Tabel 3. Hasil Analisis Regresi Moderasi

\begin{tabular}{|c|c|c|c|c|c|c|}
\hline & Model & & & Standardized & & \\
\hline & & Unstand & Doefficients & Coefficients & $\mathrm{T}$ & Sig. \\
\hline & & B & Std. Error & Beta & & \\
\hline 1 & (Constant) & -4.723 & 3.126 & & -1.511 & .141 \\
\hline & Idealisme & 0,240 & 0,063 & 0,329 & 3.818 & 0,001 \\
\hline & $\begin{array}{l}\text { Kecerdasan } \\
\text { emosional }\end{array}$ & 0,189 & 0,043 & 0,414 & 4.435 & 0,000 \\
\hline & Etika & 0,478 & 0,103 & 0,681 & 4.653 & 0,000 \\
\hline & $\begin{array}{l}\text { Kepercayaan } \\
\text { diri }\end{array}$ & 0,095 & 0,078 & 0,141 & 1.220 & 0,231 \\
\hline & X1.Z & 0,014 & 0,003 & 0,584 & 5.112 & 0,000 \\
\hline & $\mathrm{X} 2 . \mathrm{Z}$ & 0,005 & 0,002 & 0,582 & 3.484 & 0,001 \\
\hline & X3.Z & 0,014 & 0,003 & 0,802 & 4.289 & 0,000 \\
\hline & R Square & & & & & 0,837 \\
\hline & $\begin{array}{l}\text { Adjusted } \\
\text { Square }\end{array}$ & & & & & 0,801 \\
\hline & F Statistik & & & & & 23,443 \\
\hline & Signifikansi & & & & & 0,000 \\
\hline
\end{tabular}

Sumber: Data Penelitian, 2019 
Berdasarkan Tabel 3, dapat disusun persamaan regresi sebagai berikut. $Y=-4.723+240\left(X_{1)}+189\left(X_{2)}+478\left(X_{3}\right)+0,095(Z)+0,014\left(X_{1} Z\right)+0,005\left(X_{2} Z\right)+\right.\right.$ $0,014\left(X_{3} Z\right)$

Variabel idealisme $\left(X_{1}\right)$ memiliki nilai koefisien $\beta_{1}$ positif sebesar 0,240 dengan tingkat signifikansi sebesar 0,001 lebih kecil dari alpha $(0,05)$. Hasil pengujian tersebut menyatakan bahwa idealisme bernilai positif dan berpengaruh signifikan terhadap persepsi etis mahasiswa profesi akuntansi mengenai perilaku etis akuntan.

Variabel kecerdasan emosional $\left(\mathrm{X}_{2}\right)$ memiliki nilai koefisien $\beta_{2}$ positif sebesar 0,189 dengan tingkat signifikansi sebesar 0,000 lebih kecil dari alpha $(0,05)$. Hasil pengujian tersebut menyatakan bahwa kecerdasan emosional bernilai positif dan berpengaruh signifikan terhadap persepsi etis mahasiswa profesi akuntansi mengenai perilaku etis akuntan.

Variabel etika $\left(X_{3}\right)$ memiliki nilai koefisien $\beta_{3}$ positif sebesar 0,478 dengan tingkat signifikansi sebesar 0,000 lebih kecil dari alpha $(0,05)$. Hasil pengujian tersebut menyatakan bahwa etika bernilai positif dan berpengaruh signifikan terhadap persepsi etis mahasiswa profesi akuntansi mengenai perilaku etis akuntan.

Variabel interaksi $\left(\mathrm{X}_{1} . \mathrm{Z}\right)$ memiliki nilai koefisien positif sebesar 0,014 dengan tingkat signifikansi sebesar 0,000 lebih kecil dari alpha $(0,05)$. Hasil pengujian tersebut menyatakan bahwa kepercayaan diri mampu memperkuat pengaruh idealisme pada persepsi etis mahasiswa profesi akuntansi mengenai perilaku etis akuntan.

Variabel interaksi $\left(X_{2} . Z\right)$ memiliki nilai koefisien positif sebesar 0,005 dengan tingkat signifikansi sebesar 0,001 lebih kecil dari alpha $(0,05)$. Hasil pengujian tersebut menyatakan bahwa kepercayaan diri mampu memperkuat pengaruh kecerdasan emosional pada persepsi etis mahasiswa profesi akuntansi mengenai perilaku etis akuntan.

Variabel interaksi $\left(\mathrm{X}_{3} . \mathrm{Z}\right)$ memiliki nilai koefisien positif sebesar 0,014 dengan tingkat signifikansi sebesar 0,000 lebih kecil dari alpha $(0,05)$. Hasil pengujian tersebut menyatakan bahwa kepercayaan diri mampu memperkuat pengaruh etika pada persepsi etis mahasiswa profesi akuntansi mengenai perilaku etis akuntan.

Koefisien determinasi $\left(\mathrm{R}^{2}\right)$ digunakan untuk mengetahui dan mengukur kemampuan model dalam menerangkan variasi variabel independen. Pada penelitian ini menggunakan nilai adjusted $\mathrm{R}^{2}$ pada saat mengevaluasi yang mana model regresi terbaik, karena tidak seperti $\mathrm{R}^{2}$, nilai adjusted $\mathrm{R}^{2}$ dapat naik atau turun apabila satu variabel independen ditambahkan ke dalam model. Hasil uji memberikan hasil dimana diperoleh besarnya adjusted $\mathrm{R}^{2}$ (koefisien determinasi yang telah disesuaikan) pada Tabel 3 adalah 0,801. Ini berarti variasi persepsi etis dapat dipengaruhi secara signifikan oleh variabel idealisme, kecerdasan emosional, eetika, kepercayaan diri, interaksi $X_{1} . Z$, interaksi $X_{2} . Z$ dan interaksi $X_{3} . Z$ sebesar $80,1 \%$ sedangkan sisanya sebesar $19,9 \%$ dijelaskan oleh faktor-faktor lain yang tidak dijelaskan dalam penelitian ini.

Uji keterandalan model atau uji kelayakan model atau yang lebih populer disebut sebagai uji $\mathrm{F}$ merupakan tahapan awal mengidentifikasi model regresi yang diestimasi layak atau tidak. Layak (andal) disini maksudnya adalah model 
yang diestimasi layak digunakan untuk menjelaskan pengaruh variabel-variabel bebas terhadap variabel terikat. Sig. Tabel ANOVA menunjukkan besarnya angka probabilitas atau signifikansi pada perhitungan ANOVA. Nilai yang tertera digunakan untuk uji kelayanan Model Analisis (dimana sejumlah variabel $x$ mempengaruhi variabel $y)$ dengan ketentuan angka probabilitas yang baik untuk digunakan sebagai model regresi harus $<0,05$. Nilai ini bisa dilihat pada kolom Sig. Jika signifikansi < 0,05, maka Model Analisis dianggap layak. Jika nilai signifikansi $>0,05$, maka Model Analisis dianggap tidak layak. Hasil uji F dalam penelitian ini dapat dilihat pada Tabel 4 .

Tabel 4. Hasil Uji F

\begin{tabular}{lllllll}
\hline Model & & Sum of Squares & Df & Mean Square & F & Sig. \\
\hline 1 & Regression & 188.303 & 7 & 26.900 & 23.443 & $0,000^{\mathrm{a}}$ \\
& Residual & 36.719 & 32 & 1.147 & & \\
& Total & 225.021 & 39 & & & \\
\hline
\end{tabular}

Sumber: Data Penelitian, 2019

Hasil uji F (Ftest) pada Tabel 4, menunjukkan bahwa nilai signifikansi $\mathrm{P}$ value 0,000 yang lebih kecil dari $a=0,05$, ini berarti model yang digunakan pada penelitian ini adalah layak. Hasil ini memberikan makna bahwa seluruh variabel independen mampu memprediksi atau menjelaskan fenomena persepsi etis mahasiswa profesi akuntansi mengenai perilaku etis akuntan.

\section{SIMPULAN}

Hasil penelitian ini diharapkan dapat memberikan kontribsusi mengenai pengaruh idealisme, kecerdasan emosional dan etika pada persepsi etis mahasiswa profesi akuntansi mengenai perilaku etis akuntan dengan kepercayaan diri sebagai pemoderasi. Hasil uji penelitian ini ditemukan bahwa idealisme, kecerdasan emosional dan etika menunjukkan searah dengan persepsi etis yang dimiliki mahasiswa, sedangkan kepercayaan diri sebagai pemoderasi menunjukkan mampu memoderasi pengaruh idealisme, kecerdasan emosional dan etika pada persepsi etis yang dimiliki mahasiswa.

Teori moral kognitif menjelaskan bahwa penalaran moral merupakan landasan berperilaku etis. Seseorang mahasiswa dengan idealisme, kecerdasan emosional, etika dan kepercayaan diri yang tinggi akan dapat berperilaku etis sesuai dengan prinsip-prinsip moral yang berlaku.

Hasil penelitian ini diharapkan mampu memberikan implikasi pada pihak kampus guna untuk tetap meningkatkan sistem pendidikan yang ada di PPAk Fakultas Ekonomi dan Bisnis, Universitas Udayana, yang dimana tidak hanya berfokus pada ilmu namun juga menekankan pentingnya kepribadian yang dimiliki seseorang meliputi nilai etika, kejujuran dan tanggung jawab sehingga mampu menghasilkan lulusan yang berkompeten dan siap bekerja, serta meminimalisir berbagai kasus kecurangan yang melibatkan profesi akuntan.

\section{REFERENSI}

Adi Damayanthi, P. D., \& Juliarsa, G. (2016). Pengaruh Idealisme, Relativisme, Pengetahuan, Gender dan Umur pada Perilaku Tidak Etis Akuntan. E-Jurnal Akuntansi Universitas Udayana, 15(1), 1-15.

Agustian. (2004). ESQ Power Sebuah Inner Journey Melalui alIhsan, Jakarta: Arga. 
Angelis. (2005). Confidence: Percaya diri sumber sukses dan kemandirian. Jakarta: PT. Gramedia Pustaka Utama. 2005.

Aziza, N., \& Melandy, R. R. (2006). Pengaruh Kecerdasan Emosional Terhadap Tingkat Pemahaman Akuntansi, Kepercayaan Diri Sebagai Variabel Pemoderasi. Simposium Nasional..., 23-26. Retrieved from http://digilib.mercubuana.ac.id/manager/file_artikel_abstrak/Isi_Artikel_ 594677672272.pdf

Dewi, N., \& Wirama, D. (2016). Kepercayaan Diri Sebagai Pemoderasi Pengaruh Kecerdasan Emosional Dan Perilaku Belajar Pada Tingkat Pemahaman Akuntansi. E-Jurnal Akuntansi, 16(1), 615-644.

Elias, R. Z., \& Farag, M. (2010). The relationship between accounting students' love of money and their ethical perception. Managerial Auditing Journal, 25(3), 269-281. https:/ / doi.org/10.1108/02686901011026369

Fabian, V. (2019). Kasus Lapkeu Garuda: Bukti KAP Taraf Internasional Bisa Kebobolan, https://tirto.id/edi1. Accounting Ethics.

Fan, Y. H., Woodbine, G., \& Cheng, W. (2013). A study of Australian and Chinese accountants' attitudes towards independence issues and the impact on ethical judgements. Asian Review of Accounting, 21(3), 205-222. https:// doi.org/10.1108/ARA-04-2013-0027

Goleman, D. (2018). Emotional Intelligence. 25(9), 932-942. https://doi.org/10.1007/s42243-018-0133-0

Hanny, R. (2016). Interaksi Budaya Etis dan Kecerdasan Spiritual Pada Hubungan Muatan Etika dan Perilaku Etis Mahasiswa. E-Jurnal Akademi YKPN Yogyakarta, 20(1), 1-24.

Herwinda Nurmala, D. (2010). Persepsi Mahasiswa Atas Perilaku Tidak Etis Akuntan (Studi Kasus Pada Universitas Kristen Satya Wacana). Skripsi.

Intan Kurniasari, K., \& Ayu Nyoman Budiasih, I. G. (2018). Pengaruh Kecerdasan Emosional, Kecerdasan Intelektual, Love of Money pada Persepsi Mahasiswa Mengenai Etika Profesi Akuntan. E-Jurnal Akuntansi Universitas Udayana, 25(1), 773-798.

Jackling, B., Cooper, B. J., Leung, P., \& Dellaportas, S. (2007). Professional accounting bodies' perceptions of ethical issues, causes of ethical failure and ethics education. Managerial Auditing Journal, 22(9), 928-944. https:// doi.org/10.1108/02686900710829426

Kohlberg. (1969). Tahap Perkembangan Moral. http://id.wikipedia.org/wiki/tahap_perkembangan_moral_kohlberg. 1969.

Kohlberg. (1971). Kohlberg. L. 1971. Stages of Moral Development as a Basis of Moral Education. Karya Ilmiah. Tidak Diterbitkan. 1971.

Lie, L. (2009). Penggunaan MRA dengan Spss untuk Menguji Pengaruh Variabel Moderating terhadap Hubungan antara Variabel Independen dan Variabel Dependen. Jurnal Teknologi Informasi DINAMIK, XIV(2), 90-97. Retrieved from https://www.unisbank.ac.id/ojs/index.php/fti1/article/view/95/90

Lili Cahyani, N. W. S., \& Ramantha, I. W. (2018). Pengaruh Pengetahuan, Sensitivitas Etis, Idealisme pada Persepsi Etis Mahasiswa Akuntansi Atas Perilaku Etis Akuntan. E-Jurnal Akuntansi Universitas Udayana, 24(2), 1387. https:/ / doi.org/10.24843/EJA.2018.v24.i02.p21

Lubis. (2014). Akuntansi Keprilakuan (2nd ed). Jakarta: Salemba Empat. 
Lucyanda, J., \& Endro, G. (2013). Faktor-Faktor Yang Memengaruhi Perilaku Etis Mahasiswa Akuntansi Universitas Bakrie. Media Riset Akuntansi, 2(2), 1-34.

Mabil, A. N. (2019). Investigating Effects of Accounting Ethics on Quality of Financial Reporting of an Organization: Case of Selected Commercial Banks in South Sudan. Mediterranean Journal of Social Sciences, 10(1), 177-191. https:/ / doi.org/10.2478/mjss-2019-0016

Made, N., Ariyanti, H., \& Widanaputra, A. A. G. P. (2018). Pengaruh Idealisme, Relativisme Dan Etika Pada Persepsi Mahasiswa Akuntansi Atas Perilaku Etis Akuntan Fakultas Ekonomi dan Bisnis Universitas Udayana ( Unud ), Bali , Indonesia Fakultas Ekonomi dan Bisnis Universit. E-Jurnal Akuntansi Universitas Udayana, 24(3), 2197-2225.

Milyawati, A. U. (2017). Pengaruh Idealisme, Relativisme, Love of Money, Gender dan Tingkat Pengetahuan Akuntansi terhadap Persepsi Mahasiswa Akuntansi atas Perilaku Etis Akuntan. Akuntansi, 2-33.

Part, R. C. (2010). Ethics and experiments in accounting. Journal Accounting, 24(Unit 07), 1-5.

Putu Martini, Ni Putu Sri Harta Mimba, N. K. R. (2017). Pengaruh Love of Money, Organizational Cotozenship Behavior dan Kecerdasan Emosional pada Kinerja Pegawai Universitas Udayana. E-Jurnal Akuntansi, 1(6), 303328.

Rini, F. J. (2002). Kepercayaan Diri. Http://E-Psikologi.Com.

Santika Putra, K., \& Latrini, M. (2016). Pengaruh Kecerdasan Intelektual, Kecerdasan Emosional, Kecerdasan Spiritual, Komitmen Organisasi Terhadap Kinerja Auditor. E-Jurnal Akuntansi, 17(2), 1168-1195.

Shawver, T. J., Clements, L. H., \& Sennetti, J. T. (2015). How does moral intensity impact the moral judgments and whistleblowing intentions of professional accountants? In Research on Professional Responsibility and Ethics in Accounting (Vol. 19). https://doi.org/10.1108/S1574-076520150000019002

Sujana, I. K., \& Ardewi Laksmi, R. (2017). Pengaruh Kecerdasan Intelektual, Kecerdasan Emosional dan Kecerdasan Spritual terhadap Pemahaman Akuntansi. E-Jurnal Akuntansi Universitas Udayana, 21(3), 1373-1399.

Sujana, I. K., Sadha, I. M., Putu, N., \& Windika, T. (n.d.). The Effect of Intellectual Intelligence, Emotional Intelligence, Spiritual Intelligence and Adversity Intelligence on Profession Performance in Taxation Field with Locus of Control as Moderating Variable. 4531, 53-63.

Suwarno, \& Cahyano, D. (2013). Pengaruh Kecerdasan Intelektual dan Kecerdasan Emosional terhadap Perilaku Etis Mahasiswa Akuntansi dalam Praktik Pelaporan Keuangan. E-Jurnal Akuntansi Universitas Muhammadiyah, 1-18.

Yani, F. (2011). Pengaruh Kecerdasan Intelektual, Kecerdasan Emosional dan Kecerdasan Spiritual Terhadap Pemahaman Akuntansi. Jurnal Akuntansi Pendidikan. Universitas Riau, 1-14.

Yanti, S. A. \& S. (2016). Pengaruh Muatan Etika dalam Pengajaran Akuntansi Keuangan, Kecerdasan Intelektual, Kecerdasan Emosional dan Kecerdasan Spiritual terhadap Sikap Etis Mahasiswa Akuntansi. Jurnal Akuntansi, 13(02), 2-15. 